\title{
Arsenic and other heavy metals in the rivers of central Nepal
}

\author{
Steven H. Emerman \\ Department of Biology and Environmental Science, Simpson College, \\ Indianola, Iowa 50125, U.S.A \\ (Email: emerman@simpson.edu)
}

\begin{abstract}
The objective of this study was to measure fluvial $\mathrm{As}, \mathrm{Co}, \mathrm{Cu}, \mathrm{Fe}$, and $\mathrm{Zn}$ in order to determine whether central Nepal has a geographically-limited source of As. Seventeen rivers in central Nepal outside and eight rivers inside the heavily polluted Kathmandu valley were sampled monthly for six months. Outside the Kathmandu valley, fluvial As ( $11 \pm 1 \mu \mathrm{g} / \mathrm{l})$, Co (110 $\pm 30 \mu \mathrm{g} / \mathrm{l}), \mathrm{Cu}(93 \pm 4 \mu \mathrm{g} / \mathrm{l}), \mathrm{Fe}(550 \pm 80 \mu \mathrm{g} / \mathrm{l})$, and $\mathrm{Ni}(50 \pm 3 \mu \mathrm{g} / \mathrm{l})$ were over $5,550,13$, and 13 times the global averages for each respective element, while $\mathrm{Zn}(27 \pm 4 \mu \mathrm{g} / \mathrm{l})$ was very close to the global average. The only statistically significant differences between inside and outside the Kathmandu valley were $\mathrm{pH}$ (inside: $7.13 \pm 0.06$, outside: $8.13 \pm 0.06$ ), Fe (inside: $1060 \pm 90 \mu \mathrm{g} / \mathrm{l})$ and $\mathrm{Cu}$ (inside: $70 \pm 10 \mu \mathrm{g} / \mathrm{l}$ ) so that $\mathrm{Co}, \mathrm{Cu}, \mathrm{Ni}$, and $\mathrm{Zn}$ levels inside the Kathmandu valley were all naturally occurring. Fluvial As was correlated both in space and time with $\mathrm{pH}$. Outside the Kathmandu valley, fluvial As decreased when $\mathrm{pH}$ decreased, due to the increase in the number of positively-charged sorption sites on river bed sediment. Inside the polluted Kathmandu valley, fluvial As increased when $\mathrm{pH}$ decreased, due to the organic complexation of As and the negative correlation between organic matter and $\mathrm{pH}$. Central Nepal has multiple sources of As associated with mineralisation of Co, $\mathrm{Cu}, \mathrm{Fe}$, and $\mathrm{Ni}$, but not $\mathrm{Pb}-\mathrm{Zn}$.
\end{abstract}

\section{INTRODUCTION}

Much attention has focused recently on the problem of As contamination of groundwater in West Bengal and Bangladesh (Bhattacharaya et al. 1997; Dhar et al. 1997; Nickson et al. 1998). It is generally agreed that As contamination is too widespread to be due to human activities such as smelting or use of As-based pesticides (Aswathanarayana 1997). Nickson et al. (1998) and Acharyya et al. (1999, 2000) have discussed possible natural sources of As in As-bearing rock units of India and Bangladesh (Bhattacharyya 1972; Das 1977; Ghosh and De 1995). Acharyya et al. (2000) suggested also that the ultimate bedrock source of As may lie in the upper reaches of the Ganges River system. Most workers have investigated not the ultimate source of As, but the mechanism by which As is released from soil or sediment into groundwater (Badal et al. 1996; Mallick and Rajgopal 1996; Acharyya et al. 1999, 2000; Nickson et al. 2000; McArthur et al. 2001; Shanker et al. 2001; Appelo et al. 2002; Bose and Sharma 2002; Harvey et al. 2002; Emerman 2004). In a comprehensive review of the occurrence of As in natural waters, Smedley and Kinniburgh (2002) wrote with regard to the As-bearing sediments in south Asia, "These sediments are derived from the drainage systems of 3 major rivers (Ganges, Brahmaputra, and Meghna) which are themselves sourced from a wide area of the Himalaya. Therefore, while it could be argued that the source of much of the As in the Bengal Basin sediments is derived from specific mineralised areas in the source region, these are likely to be so widespread as to be academic and of little practical relevance."

Arsenic contamination in groundwater is also known to occur in the Terai region of Nepal (Fig. 1a), although it has not been so well documented as in the other parts of south Asia. As of March 2002, nearly 27\% of tested wells exceeded the World Health Organisation (WHO) guideline value of $10 \mu \mathrm{g} / \mathrm{l}$, while $5 \%$ exceeded the Interim Nepal Standard of 50 $\mu \mathrm{g} / \mathrm{l}$. The most affected districts were Rautahat, Nawalparasi, Parsa and Bara in the central Terai (Neku and Tandukar 2002). The Terai region is much closer to possible Himalayan Asbearing source rocks than are West Bengal and Bangladesh. Therefore, it is much more likely that it is possible to identify the sources of As mineralisation that affects the Terai region than other parts of south Asia.

The first objective of this study was to measure As concentrations in rivers that drain through central Nepal into the Terai region. If there were one or more As-rich watersheds, then it might be possible to roughly locate the sources of As and to describe the transport of As through surface and groundwater into and through the Terai. The second objective was to measure in the same rivers the concentrations of $\mathrm{Co}, \mathrm{Cu}, \mathrm{Fe}, \mathrm{Ni}$, and $\mathrm{Zn}$, the elements most commonly associated with As (Boyle and Jonasson 1973). If there were correlations between As and one or more heavy metals, then it might be possible to locate sources of As more precisely based on knowledge of mineral deposits of 
Table 1a: Rivers sampled in central Nepal outside the Kathmandu valley

\begin{tabular}{|c|c|c|c|c|}
\hline No. & Name $^{a}$ & Latitude (N) & Longitude (E) & Description and Sampling Dates \\
\hline 1 & Aruba $^{\mathrm{b}}$ & $27^{\circ} 36^{\prime} 56.4^{\prime \prime}$ & $83^{\circ} 57^{\prime} 13.2^{\prime \prime}$ & Bridge on Mahendra E-W Highway $2 / 13,3 / 10,4 / 23,5 / 21,6 / 23,7 / 14$ \\
\hline 2 & Aruwa $^{c}$ & $27^{\circ} 10^{\prime} 49.9^{\prime \prime}$ & $85^{\circ} 10^{\prime} 15.8^{\prime \prime}$ & Bridge on Mahendra E-W Highway $2 / 20,3 / 19,4 / 23,5 / 22,6 / 24,7 / 15$ \\
\hline 3 & Bagmati & $27^{\circ} 07^{\prime} 58.2^{\prime \prime}$ & $85^{\circ} 28^{\prime} 54.9^{\prime \prime}$ & Bridge on Mahendra E-W Highway $2 / 20,3 / 19,4 / 23,5 / 22,6 / 24,7 / 15$ \\
\hline 4 & Betara & $27^{\circ} 34^{\prime} 15.7^{\prime \prime}$ & $84^{\circ} 13^{\prime} 03.4^{\prime \prime}$ & Confluence with Rapti River 2/13, 3/10, 4/24, 5/21, 6/23, 7/14 \\
\hline 5 & Binai & $27^{\circ} 35^{\prime} 02.8^{\prime \prime}$ & $83^{\circ} 52^{\prime} 28.9^{\prime \prime}$ & Bridge on Mahendra E-W Highway $2 / 13,3 / 10,4 / 23,5 / 21,6 / 23,7 / 14$ \\
\hline 6 & Budhigandaki & $27^{\circ} 48^{\prime} 53.3^{\prime \prime}$ & $84^{\circ} 46^{\prime} 55.4^{\prime \prime}$ & Confluence with Trishuli River 2/12, 3/11, 4/22, 5/20,6/22, 7/13 \\
\hline 7 & Hardinath $^{\mathrm{d}}$ & $27^{\circ} 00^{\prime} 49.8^{\prime \prime}$ & $85^{\circ} 44^{\prime} 29.9^{\prime \prime}$ & Bridge on Mahendra E-W Highway 5/22, 6/24, 7/15 \\
\hline 8 & Jhim $^{e}$ & $27^{\circ} 02^{\prime} 10.0^{\prime \prime}$ & $85^{\circ} 40^{\prime} 22.4^{\prime \prime}$ & Bridge on Mahendra E-W Highway 5/22, 6/24, 7/15 \\
\hline 9 & Kaligandaki & $27^{\circ} 44^{\prime} 44.2^{\prime \prime}$ & $84^{\circ} 25^{\prime} 29.4^{\prime \prime}$ & Confluence with Trishuli River 2/12, 3/11, 4/22, 5/20, 6/25, 7/13 \\
\hline 10 & Kamala & $26^{\circ} 52^{\prime} 38.8^{\prime \prime}$ & $86^{\circ} 08^{\prime} 13.3^{\prime \prime}$ & Bridge on Mahendra E-W Highway $2 / 20,3 / 19,4 / 23,5 / 22,6 / 24,7 / 15$ \\
\hline 11 & Macha $^{\mathrm{f}}$ & $27^{\circ} 00^{\prime} 17.1^{\prime \prime}$ & $85^{\circ} 47^{\prime} 45.2^{\prime \prime}$ & Bridge on Mahendra E-W Highway 5/22, 6/24, 7/15 \\
\hline 12 & Malekhu & $27^{\circ} 48^{\prime} 24.0^{\prime \prime}$ & $84^{\circ} 50^{\prime} 00.5^{\prime \prime}$ & Confluence with Trishuli River 2/12, 3/11, 4/22, 5/20, 6/22, 7/13 \\
\hline 13 & Marsyandi & $84^{\circ} 51^{\prime} 55.2^{\prime \prime}$ & $84^{\circ} 32^{\prime} 53.4^{\prime \prime}$ & Confluence with Trishuli River 2/12, 3/11, 4/22, 5/20,6/22, 7/13 \\
\hline 14 & Narayani & $27^{\circ} 41^{\prime} 54.9^{\prime \prime}$ & $84^{\circ} 25^{\prime} 11.3^{\prime \prime}$ & Bridge on Mahendra E-W Highway $2 / 13,3 / 11,4 / 23,5 / 20,6 / 23,7 / 14$ \\
\hline 15 & Rapti & $27^{\circ} 34^{\prime} 02.1^{\prime \prime}$ & $84^{\circ} 12^{\prime} 54.9^{\prime \prime}$ & Near Meghauli 3/10, 4/24, 5/21, 6/23, 7/14 \\
\hline 16 & Seti & $27^{\circ} 49^{\prime} 16.8^{\prime \prime}$ & $84^{\circ} 27^{\prime} 15.9^{\prime \prime}$ & Confluence with Trishuli River 2/14, 3/11, 4/22, 5/20,6/22, 7/13 \\
\hline 17 & Trishuli & $27^{\circ} 48^{\prime} 06.6^{\prime \prime}$ & $84^{\circ} 52^{\prime} 17.7^{\prime \prime}$ & Gajuritar, upstream from Malekhu 2/12, 3/11, 4/22, 5/20, 6/22, 7/13 \\
\hline
\end{tabular}

${ }^{a}$ River names are according to DS (2002a,b) and may differ from local names (see below).

${ }^{b}$ Local name is Arun. $\quad{ }^{c}$ Local name is Bakeya. $\quad{ }^{\mathrm{d}}$ Local name is Bankhe. $\quad{ }^{\mathrm{e}}$ Local name is Phuljor. $\quad{ }^{\mathrm{f}}$ Local name is Marha.

Table 1b: Rivers sampled in central Nepal inside the Kathmandu valley

\begin{tabular}{c|l|c|c|c}
\hline No. & Name & Latitude (N) & Longitude (E) & Description \\
\hline 18 & Bagmati & $27^{\circ} 41^{\prime} 11.7^{\prime \prime}$ & $85^{\circ} 20^{\prime} 39.7^{\prime \prime}$ & Min Bhawan bridge \\
\hline 19 & Bagmati & $27^{\circ} 41^{\prime} 23.0^{\prime \prime}$ & $85^{\circ} 18^{\prime} 56.2^{\prime \prime}$ & Thapathali bridge \\
\hline 20 & Balkhu & $27^{\circ} 41^{\prime} 05.2^{\prime \prime}$ & $85^{\circ} 18^{\prime} 00.2^{\prime \prime}$ & Balkhu bridge \\
\hline 21 & Bisnumati & $27^{\circ} 41^{\prime} 54.3^{\prime \prime}$ & $85^{\circ} 18^{\prime} 08.2^{\prime \prime}$ & Teku Masan bridge \\
\hline 22 & Dhobi & $27^{\circ} 41^{\prime} 24.6^{\prime \prime}$ & $85^{\circ} 19^{\prime} 42.2^{\prime \prime}$ & Thapagaon bridge \\
\hline 23 & Manahara & $27^{\circ} 40^{\prime} 24.2^{\prime \prime}$ & $85^{\circ} 20^{\prime} 28.8^{\prime \prime}$ & Balkumari bridge \\
\hline 24 & Nakhu & $27^{\circ} 39^{\prime} 45.3^{\prime \prime}$ & $85^{\circ} 18^{\prime} 22.5^{\prime \prime}$ & Nakhu Bazar bridge \\
\hline 25 & Teta & $27^{\circ} 39^{\prime} 57.6^{\prime \prime}$ & $85^{\circ} 20^{\prime} 01.0^{\prime \prime}$ & Ashok Stupa bridge \\
\hline
\end{tabular}

heavy metals (Sharma 1995a). The third objective was to compare concentrations of As and other heavy metals inside and outside the heavily polluted Kathmandu valley in order to determine which heavy metal concentrations are naturally occurring and which are due to human activities.

\section{MATERIALS AND METHODS}

Seventeen rivers in central Nepal outside the Kathmandu valley and eight rivers inside the Kathmandu valley were sampled monthly over six months from February to July 2003 (Tables 1a, b and Fig. 1a, b). Rivers inside the Kathmandu valley were sampled on February 6, March 5, March 30, May 4, June 1, and July 1. Rivers outside the Kathmandu valley were sampled within nine days of one another in February and March and within three days of one another thereafter (see Table 1a for dates). The Hardinath (No. 7, Table 1a and Fig. 1a), Jhim (No. 8), and Macha Rivers (No. 11) were dry until the pre-monsoon rains of May and were sampled only three times. The Rapti River (No. 15) was not sampled in
February due to the author's mistaking the Betara River (No. 4), a tributary of the Rapti River, for the Rapti River itself. Thereafter, both the Betara and Rapti Rivers were sampled monthly. The two sampling locations are indistinguishable on the scale of Fig. 1a.

River samples were collected in duplicate 250-ml Nalgene bottles and $2 \mathrm{M} \mathrm{HNO}_{3}$ was added until $\mathrm{pH}<2$ (Sanders 1998). The river $\mathrm{pH}$ was measured on-site with the Oakton $\mathrm{pH}$ Tester with ATC (precise to $0.1 \mathrm{pH}$ units) until June and with the Hanna HI $9025 \mathrm{pH}$ meter (precise to $0.01 \mathrm{pH}$ units) in July. Duplicate testing in July verified that the two $\mathrm{pH}$ meters gave the same result. The river samples were not filtered, but were allowed to stand for at least 5 days to allow the suspended matter to settle (Salbu et al. 1979). Just prior to analysis, 2M KOH was added until pH > 4 (Sanders 1998). Arsenic was measured with the Hach Arsenic Test Kit, Co and $\mathrm{Ni}$ with the Hach Nickel / Cobalt Pocket Colorimeter, $\mathrm{Cu}$ with the Hach Copper Pocket Colorimeter, Fe with the Hach Total Iron FerroVer Method Pocket Colorimeter, and Zn with 


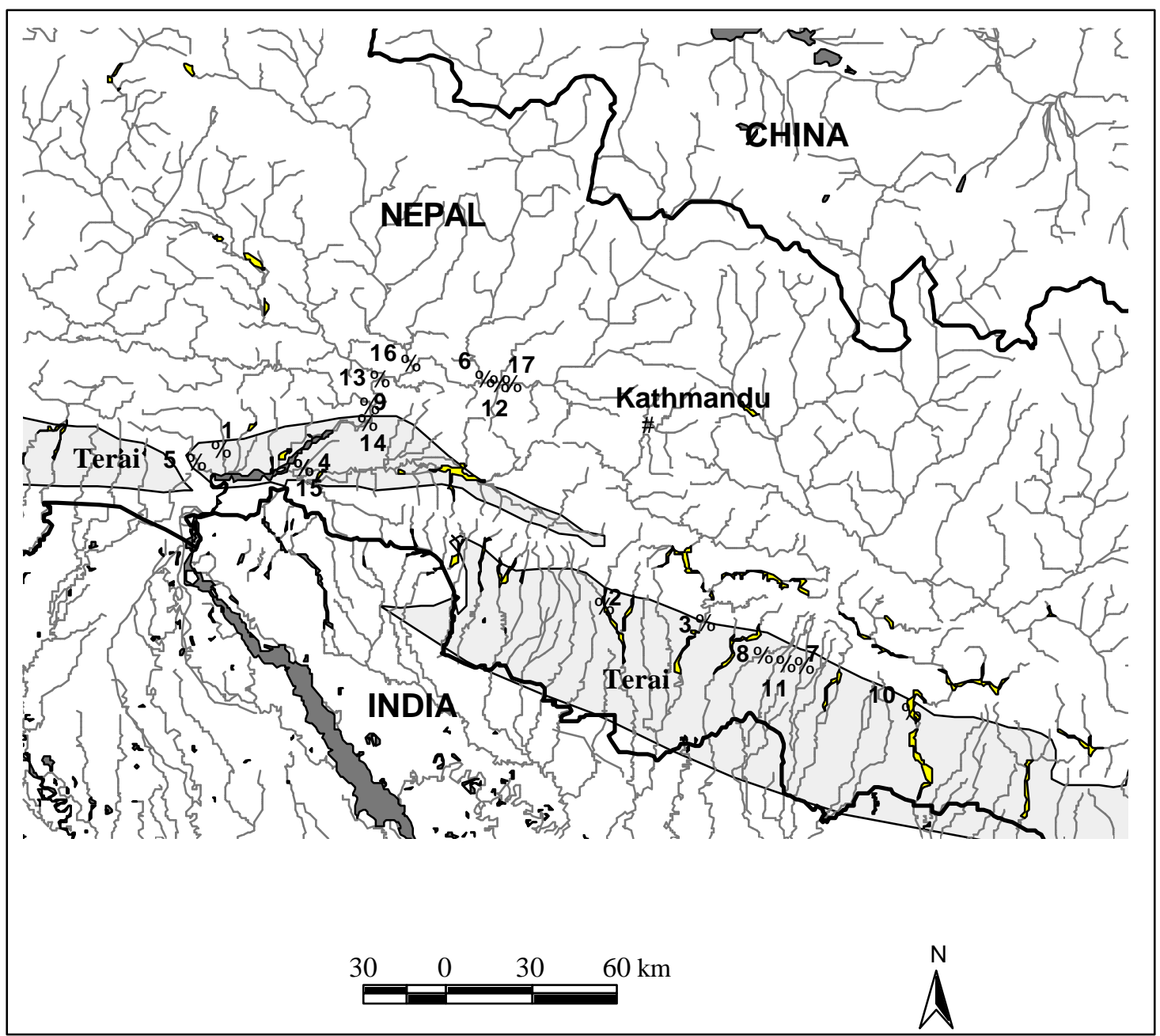

Fig. 1a: Sampling locations for rivers outside of the Kathmandu valley. See Table 1a for river names. Locations nos. 4 and 15 are indistinguishable at map scale. Drainage system and boundaries of Terai are based on Hearn et al. (2001).

the Hach DR/2010 Portable Datalogging Spectrophotometer. The Hach Arsenic Test Kit could be read reliably at 0, 5, 10, 20, $30,40,50,60$, and $70 \mu \mathrm{g} / \mathrm{l}$. The other instruments all had precision and minimum detection value of $10 \mu \mathrm{g} / \mathrm{l}$. Outliers were re-measured with the duplicate sample. Elemental concentrations were corrected for the dilution with acid and base.

\section{RESULTS}

Tables $2 \mathrm{a}$ and $2 \mathrm{~b}$ show $\mathrm{pH}$ and $\mathrm{As}, \mathrm{Co}, \mathrm{Cu}, \mathrm{Fe}, \mathrm{Ni}$, and $\mathrm{Zn}$ concentrations averaged over the six-month period for rivers outside and inside the Kathmandu valley. Other workers (e.g., Lenvik et al. 1978; Salbu et al. 1979) have computed geometric means for fluvial chemical data under the assumption that geochemical data follow a log normal distribution. However, recently Reimann and Filzmoser (2000) have criticised this assumption and argued that logtransformed data rarely are a better fit to a normal distribution than the untransformed data. Moreover, a logarithmic transformation requires an additional assumption about how to handle values that fall below the detection limit. A standard test for a normal distribution is that the cumulative frequency data should lie on a straight line when plotted against a probability scale (Reimann and Filzmoser 2000). The above test was applied to each of the 14 data sets for $\mathrm{pH}, \mathrm{As}, \mathrm{Cu}, \mathrm{Co}, \mathrm{Fe}, \mathrm{Ni}$, and $\mathrm{Zn}$, outside and inside the Kathmandu valley (results not shown). In no case was it found that log-transformed data more closely followed a normal distribution than untransformed data. Therefore, arithmetic, rather than geometric means, were calculated (Tables 2a, b). Statistical significance was determined by $\mathrm{P}<0.05$ using the T-test (Tables $2 \mathrm{~b}, 3$ ), which assumes that data follow a normal distribution.

Table 2a shows that there is not a small set of As-rich rivers, but that almost all rivers in central Nepal show elevated levels of As. In central Nepal outside the Kathmandu valley the average fluvial As concentration $(11 \pm 1 \mu \mathrm{g} / \mathrm{l})$ was over five times the global average $(2 \mu \mathrm{g} / \mathrm{l})$ (Drever 1997). Only the Kaligandaki River (No. 9) and the ephemeral Macha 


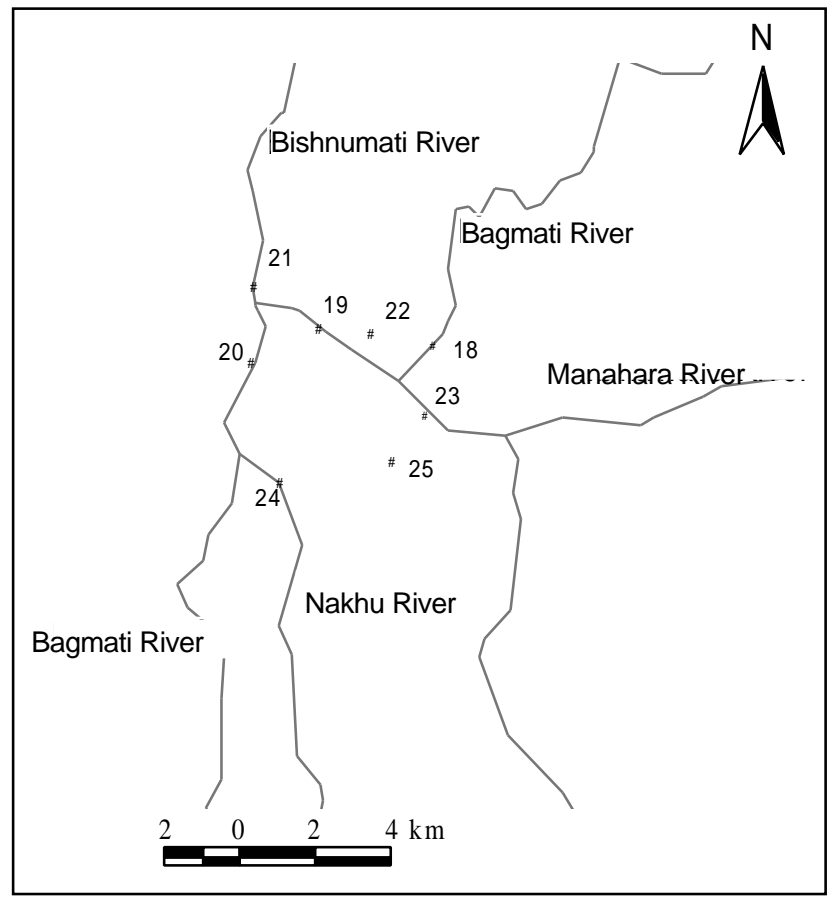

Fig. 1b: Sampling locations for rivers inside of the Kathmandu valley. See Table $1 \mathrm{~b}$ for river names. Drainage system based on Hearn et al. (2001)
River (No. 11) did not show elevated As levels. Moreover, nearly all rivers outside the Kathmandu valley showed elevated levels of $\mathrm{Co}, \mathrm{Cu}, \mathrm{Fe}$, and $\mathrm{Ni}$. The average $\mathrm{Co}$ concentration $(110 \pm 30 \mu \mathrm{g} / \mathrm{l})$ was over 550 times the global average $(0.2 \mu \mathrm{g} / \mathrm{l})$, the average $\mathrm{Cu}$ concentration $(93 \pm 4 \mu \mathrm{g} / \mathrm{l})$ was over 13 times the global average $(7 \mu \mathrm{g} / \mathrm{l})$, the average $\mathrm{Fe}$ concentration $(550 \pm 80 \mu \mathrm{g} / \mathrm{l})$ was over 13 times the global average $(40 \mu \mathrm{g} / \mathrm{l})$, and the average Ni concentration $(50 \pm 3$ $\mu \mathrm{g} / \mathrm{l})$ was 25 times the global average $(2 \mu \mathrm{g} / \mathrm{l})$ (Drever 1997). On the other hand, the average $\mathrm{Zn}$ concentration $(27 \pm 4 \mu \mathrm{g} / \mathrm{l})$ was very close to the global average $(30 \mu \mathrm{g} / \mathrm{l})$.

Table $2 \mathrm{~b}$ compares $\mathrm{pH}$ and $\mathrm{As}, \mathrm{Co}, \mathrm{Cu}, \mathrm{Fe}, \mathrm{Ni}$ and $\mathrm{Zn}$ concentrations inside and outside the Kathmandu valley. The difference between the average $\mathrm{pH}$ inside the Kathmandu valley $(7.31 \pm 0.06)$ and outside the Kathmandu valley $(8.13$ \pm 0.04 ) is statistically significant. This difference is probably due to the decomposition of large amounts of organic matter in the rivers of the Kathmandu valley (Sharma 1988, 1995b, 1997). The difference between the average Fe concentration inside the Kathmandu valley $(1060 \pm 90 \mu \mathrm{g} / \mathrm{l})$ and outside the Kathmandu valley $(550 \pm 80 \mu \mathrm{g} / \mathrm{l})$ is also statistically significant, probably due to the many rusted pipes that empty into the rivers of the Kathmandu valley (Sharma 1988, 1995b, 1997). Inside the Kathmandu valley the As $(15 \pm 2 \mu \mathrm{g} / \mathrm{l})$, Co $(170 \pm 30 \mu \mathrm{g} / \mathrm{l}), \mathrm{Ni}(80 \pm 10 \mu \mathrm{g} / \mathrm{l})$, and $\mathrm{Zn}(40 \pm 10 \mu \mathrm{g} / \mathrm{l})$ concentrations are not statistically different from the concentrations outside the Kathmandu valley, indicating that elevated levels of fluvial As, $\mathrm{Co}$, and $\mathrm{Ni}$ are naturally occurring in the Kathmandu valley, while the $\mathrm{Zn}$ level is simply the global background. It is interesting that the $\mathrm{Cu}$ concentration

Table 2a: Average pH, $\mathrm{As}, \mathrm{Co}, \mathrm{Cu}, \mathrm{Fe}, \mathrm{Ni}$, and $\mathrm{Zn}$ concentrations $(\mu \mathrm{g} / \mathrm{l})$ for rivers in central Nepal outside the Kathmandu valley, sampled monthly (February-July, 2003)

\begin{tabular}{c|c|c|c|c|c|c|c}
\hline No. & $\mathbf{p H}$ & $\mathbf{A s}$ & $\mathbf{C o}$ & $\mathbf{C u}$ & $\mathbf{F e}$ & $\mathbf{N i}$ & $\mathbf{Z n}$ \\
\hline 1 & $8.16(0.09)^{\mathrm{a}}$ & $13(5)$ & $60(60)$ & $100(20)$ & $180(70)$ & $30(20)$ & $30(10)$ \\
\hline 2 & $8.3(0.1)$ & $9(4)$ & $70(40)$ & $90(10)$ & $600(200)$ & $30(20)$ & $40(10)$ \\
\hline 3 & $8.2(0.1)$ & $11(5)$ & $90(60)$ & $90(10)$ & $600(300)$ & $50(30)$ & $40(20)$ \\
\hline 4 & $7.99(0.06)$ & $16(5)$ & $20(10)$ & $100(10)$ & $180(10)$ & $8(5)$ & $5(2)$ \\
\hline 5 & $8.06(0.07)$ & $13(4)$ & $200(100)$ & $80(10)$ & $600(300)$ & $70(50)$ & $20(10)$ \\
\hline 6 & $8.26(0.07)$ & $13(4)$ & $30(10)$ & $90(20)$ & $900(500)$ & $30(20)$ & $30(10)$ \\
\hline 7 & $7.8(0.6)$ & $8(4)$ & $400(100)$ & $60(50)$ & $1300(500)$ & $180(70)$ & $0(0)$ \\
\hline 8 & $8.3(0.3)$ & $13(5)$ & $1000(500)$ & $50(50)$ & $2900(900)$ & $400(300)$ & $20(10)$ \\
\hline 9 & $8.1(0.1)$ & $4(2)$ & $40(20)$ & $130(10)$ & $300(200)$ & $10(10)$ & $40(30)$ \\
\hline 10 & $8.0(0.2)$ & $8(3)$ & $50(40)$ & $100(20)$ & $500(300)$ & $20(20)$ & $10(10)$ \\
\hline 11 & $7.9(0.3)$ & $2(1)$ & $260(60)$ & $80(60)$ & $1200(400)$ & $110(40)$ & $30(20)$ \\
\hline 12 & $8.4(0.1)$ & $9(4)$ & $10(10)$ & $100(20)$ & $200(100)$ & $10(10)$ & $7(4)$ \\
\hline 13 & $8.20(0.06)$ & $12(5)$ & $20(10)$ & $80(10)$ & $150(70)$ & $10(10)$ & $30(20)$ \\
\hline 14 & $7.9(0.1)$ & $13(5)$ & $60(20)$ & $110(10)$ & $140(30)$ & $30(10)$ & $30(20)$ \\
\hline 15 & $8.2(0.1)$ & $14(3)$ & $60(20)$ & $80(10)$ & $400(200)$ & $30(10)$ & $40(20)$ \\
\hline 16 & $8.26(0.07)$ & $13(4)$ & $80(80)$ & $90(10)$ & $200(100)$ & $90(90)$ & $20(10)$ \\
\hline 17 & $8.0(0.2)$ & $13(3)$ & $50(20)$ & $100(10)$ & $700(400)$ & $20(10)$ & $40(10)$ \\
\hline Average & $8.13(0.04)$ & $11(1)$ & $110(30)$ & $93(4)$ & $550(80)$ & $50(3)$ & $27(4)$ \\
\hline Global & & 2 & 0.2 & 7 & 40 & & 2 \\
Average ${ }^{b}$ & & & & & & & 30 \\
\hline
\end{tabular}

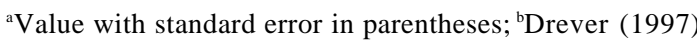


Table 2b: Average pH, As, $\mathrm{Co}, \mathrm{Cu}, \mathrm{Fe}, \mathrm{Ni}$, and $\mathrm{Zn}$ concentrations $(\mu \mathrm{g} / \mathrm{l})$ for rivers in central Nepal inside the Kathmandu valley, sampled monthly (February-July, 2003)

\begin{tabular}{c|c|c|c|c|c|c|c}
\hline No. & pH & As & Co & Cu & Fe & Ni & Zn \\
\hline 18 & $7.1(0.1)^{\text {a }}$ & $12(4)$ & $300(100)$ & $40(20)$ & $1200(200)$ & $130(40)$ & $50(30)$ \\
\hline 19 & $7.2(0.1)$ & $12(4)$ & $180(60)$ & $50(10)$ & $1300(100)$ & $70(30)$ & $70(30)$ \\
\hline 20 & $7.2(0.1)$ & $15(4)$ & $60(30)$ & $80(10)$ & $1400(400)$ & $20(10)$ & $7(4)$ \\
\hline 21 & $7.11(0.05)$ & $18(5)$ & $210(90)$ & $80(30)$ & $900(200)$ & $80(40)$ & $40(20)$ \\
\hline 22 & $7.01(0.06)$ & $30(10)$ & $400(100)$ & $70(20)$ & $1200(400)$ & $160(40)$ & $90(40)$ \\
\hline 23 & $7.26(0.08)$ & $18(4)$ & $80(30)$ & $80(10)$ & $1400(200)$ & $40(20)$ & $15(4)$ \\
\hline 24 & $8.0(0.2)$ & $6(3)$ & $50(20)$ & $90(10)$ & $410(80)$ & $30(10)$ & $40(40)$ \\
\hline 25 & $7.7(0.2)$ & $10(4)$ & $50(20)$ & $70(10)$ & $800(200)$ & $80(60)$ & $20(10)$ \\
\hline Avg. & $7.31(0.06)^{* * *}$ & $15(2)$ & $170(30)$ & $70(10)^{* *}$ & $1060(90)^{* * *}$ & $80(10)$ & $40(10)$ \\
\hline
\end{tabular}

${ }^{a}$ Value with standard error in parentheses

$*, * *, * * *$ indicates difference between value inside and outside the Kathmandu valley is statistically significant at the $95 \%, 99 \%$ and 99.9\% confidence levels

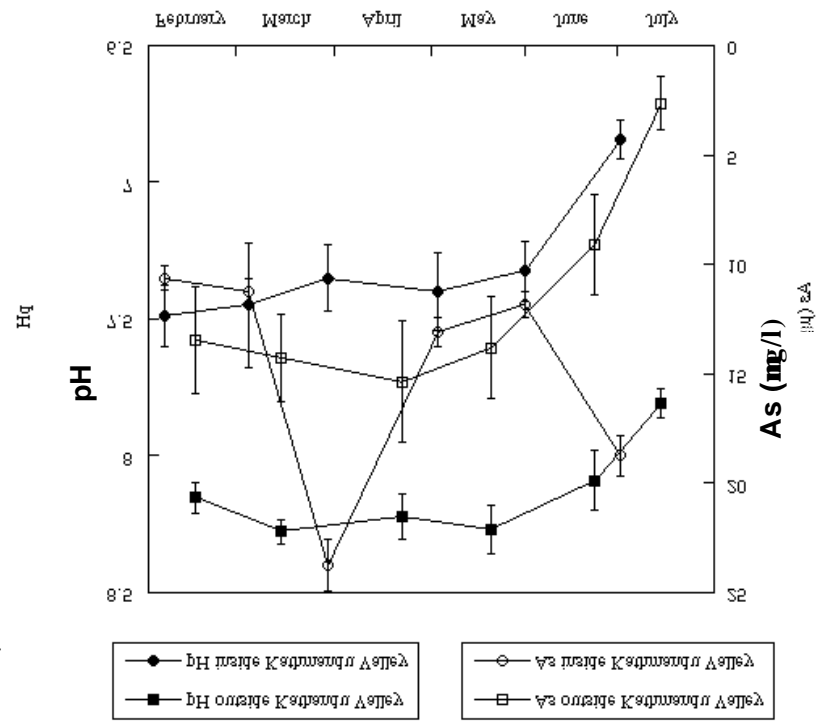

Fig. 2: Monthly variation in $\mathrm{pH}$ and Arsenic for rivers inside and outside of the Kathmandu valley. Arsenic outside of Kathmandu valley and $\mathrm{pH}$ inside and outside of the Kathmandu valley show similar trends. The onset of monsoon season causes both $\mathrm{pH}$ and As to decrease. Arsenic inside the Kathmandu valley increases with the onset of monsoon due to the increase in fluvial organic matter and the organic complexation of As. The early spring spike in As inside the Kathmandu valley is anomalous

is higher outside the Kathmandu valley ( $93 \pm 4 \mu \mathrm{g} / \mathrm{l})$ than inside $(70 \pm 10 \mu \mathrm{g} / \mathrm{l})$ and the difference is statistically significant. The difference is probably due to the relative lack of copper deposits inside of the Kathmandu valley aside from Phulchauki and Chobhar (Sharma 1995a) and emphasises that fluvial $\mathrm{Cu}$ in the Kathmandu valley is naturally occurring.

The important question is what distinguishes a relatively low-As river from a relatively high-As river in central Nepal. Table 3 compares the four rivers outside the Kathmandu valley with relatively low As concentration (Hardinath (No.
Table 3: Comparison of average $\mathrm{pH}$ and $\mathrm{Co}, \mathrm{Cu}, \mathrm{Fe}, \mathrm{Ni}$, and $\mathrm{Zn}$ concentrations for low-As $(\leq 8 \mu \mathrm{g} / \mathrm{l})$ and high-As $(>9 \mu \mathrm{g} / \mathrm{l})$ rivers in central Nepal outside of the Kathmandu valley

\begin{tabular}{l|c|c}
\hline & Low-As Rivers & High-As Rivers \\
\hline $\mathbf{A s}(\mu \mathbf{g} / \mathbf{l})$ & $6 \pm 2^{\text {a }}$ & $12 \pm 1^{*}$ \\
\hline $\mathbf{p H}$ & $7.97 \pm 0.07$ & $8.16 \pm 0.04^{*}$ \\
\hline $\mathbf{C o}(\mu \mathbf{g} / \mathbf{l})$ & $190 \pm 90$ & $130 \pm 70$ \\
\hline $\mathbf{C u}(\mu \mathbf{g} / \mathbf{l})$ & $90 \pm 20$ & $90 \pm 4$ \\
\hline $\mathbf{F e}(\mu \mathbf{g} / \mathbf{l})$ & $800 \pm 200$ & $600 \pm 200$ \\
\hline $\mathbf{N i}(\mu \mathbf{g} / \mathbf{l})$ & $80 \pm 40$ & $60 \pm 30$ \\
\hline $\mathbf{Z n}(\mu \mathbf{g} / \mathbf{l})$ & $20 \pm 10$ & $27 \pm 3$ \\
\hline
\end{tabular}

${ }^{a}$ Value \pm standard error

*indicates difference between value for low-As and high-As river is statistically significant at the $95 \%$ confidence level

7) $(8 \pm 4 \mu \mathrm{g} / \mathrm{l})$, Kaligandaki (No. 9) $(4 \pm 2 \mu \mathrm{g} / \mathrm{l})$, Kamala (No. 10) $(8 \pm 3 \mu \mathrm{g} / \mathrm{l})$ and Macha (No. 11) $(2 \pm 1 \mu \mathrm{g} / \mathrm{l}))$ with the remaining rivers with $\mathrm{As}>9 \mu \mathrm{g} / \mathrm{l}$. The $\mathrm{Co}, \mathrm{Cu}, \mathrm{Fe}, \mathrm{Ni}$, and $\mathrm{Zn}$ concentrations of the two sets of rivers are very similar. The only statistically significant difference is the $\mathrm{pH}$, which is lower for the low-As rivers $(7.97 \pm 0.07)$ than the high-As rivers $(8.16 \pm 0.04)$. Since As occurs in aqueous form as an oxyanion, it is expected that it would be desorbed from sediment when $\mathrm{pH}$ increases. Normally sediment has more negatively charged sorption sites at high $\mathrm{pH}$ and more positively charged sorption sites at low pH (Drever 1997). Attempts to correlate As with either $\mathrm{Co}, \mathrm{Cu}, \mathrm{Fe}, \mathrm{Ni}$ or $\mathrm{Zn}$, or combinations of the above elements, were uniformly unsuccessful for rivers either outside or inside the Kathmandu valley.

Fig. 2 shows the monthly variation in $\mathrm{pH}$ and As inside and outside the Kathmandu valley. Points inside and outside of the Kathmandu valley are offset in time, since they were not measured on the same day of the month. Points outside the Kathmandu valley are plotted on the average day of sampling for each month. The average $\mathrm{pH}$ inside and outside the Kathmandu valley showed remarkably similar trends with a roughly constant $\mathrm{pH}$ until the onset of the monsoon in June introduced relatively acidic rainwater into all rivers. 


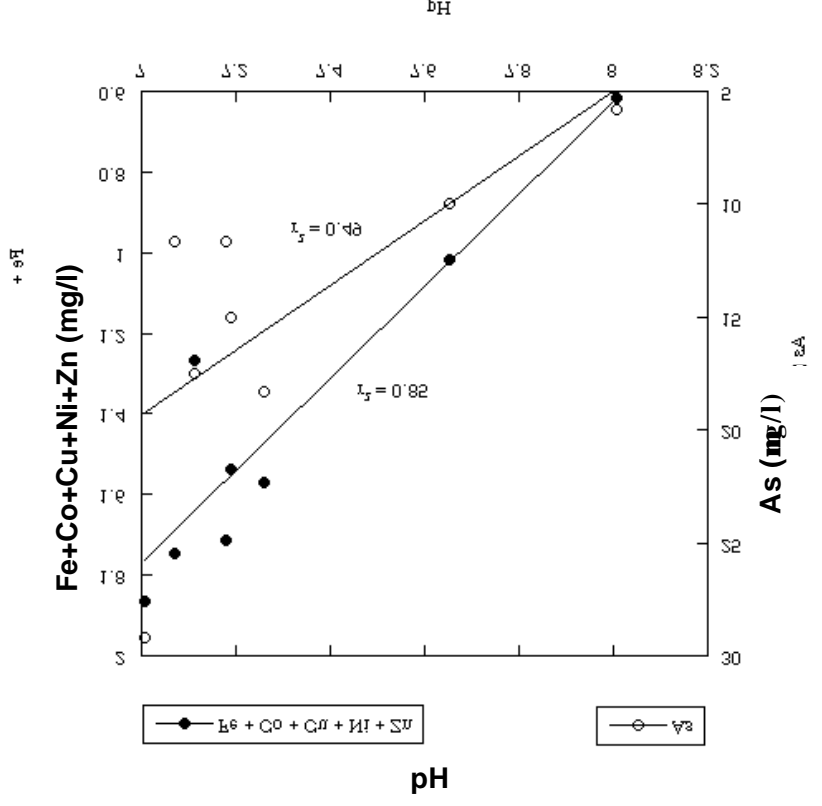

Fig. 3: Dependence of sum of measured cations $(\mathrm{Fe}+\mathrm{Co}+$ $\mathrm{Cu}+\mathrm{Ni}+\mathrm{Zn}$ ) and measured anion (As) upon $\mathrm{pH}$ for rivers inside of the Kathmandu valley. The negative correlation of both cations and anions with $\mathrm{pH}$ implies that ions are mobilised by organic complexation

Outside the Kathmandu valley, the As level also had a similar trend. Arsenic was roughly constant until the decrease in $\mathrm{pH}$ caused sorption of As onto sediment and a drop in fluvial As. The monthly variation in As inside of the Kathmandu valley was more complicated. The increase in fluvial organic matter at the beginning of the monsoon (Sharma 1988, 1995b, 1997) could have resulted in increased fluvial As due to complexation by organic matter (Waslenchuk 1979). It is unclear what could have caused the spike in As inside the Kathmandu valley on March 30.

Fig. 3 shows the dependence of the sum of all measured cations $(\mathrm{Fe}+\mathrm{Co}+\mathrm{Cu}+\mathrm{Ni}+\mathrm{Zn})$ and the measured anion $\mathrm{As}$ on $\mathrm{pH}$ for rivers inside the Kathmandu valley. Each point represents a sampling location averaged over all 6 months (Table 2b). Both cations and anions were negatively correlated with $\mathrm{pH}$. Such similar behaviour is inconsistent with sorption and desorption of ions from charged sites on sediment. Such behaviour would be expected if the dominant process for removing both cations and anions from sediment was organic complexation since the addition of organic matter will decrease $\mathrm{pH}$ (Waslenchuk 1979).

\section{DISCUSSION}

Related studies include fluvial As in India (Pandey et al. 2002), fluvial $\mathrm{pH}$ and $\mathrm{Fe}$ in rivers in Nepal inside the Kathmandu valley (Sharma 1997), and As in river bed sediment in Bangladesh (Datta and Subramanian 1997) and Pakistan (Halfpenny and Mazzucchelli 1999). Pandey et al.
(2002) investigated high levels of groundwater As in Rajnandgaon District, Chhattisgarh State, India, outside the Bengal Delta Plain, and measured fluvial As in the Shivnath River whose catchment lies in the region with high groundwater As. Pandey at al. (2002) found that fluvial As was undetectable until it began to rise with the onset of the monsoon in June, reached a maximum in July at $60 \mu \mathrm{g} / 1$, and returned to undetectable by October. As discussed above, elevated fluvial As during the monsoon may be related to elevated levels of fluvial organic matter and organic complexation of As. Aside from the present study, there do not appear to be any published studies of fluvial As in the rivers that drain into West Bengal or Bangladesh.

Sharma (1997) reported measurements of $\mathrm{pH}$ in the Kathmandu valley carried out in 1988, 1993, and 1995. Taking only those measurements that match the same sampling locations as the present study, average $\mathrm{pH}$ was $7.55(\mathrm{~N}=4)$ in $1988,7.15(\mathrm{~N}=4)$ in 1993 , and $7.21(\mathrm{~N}=8)$ in 1995. This small data set and the present study (average $\mathrm{pH}=7.31$, see Table $2 \mathrm{~b}$ ) do not show any decrease in river $\mathrm{pH}$ over the past 10 years, despite the increase in pollution. Sharma (1997) also reported Fe concentrations measured in 1993 and 1995. Again taking only the measurements that match the sampling locations of this study, average Fe was $900 \mu \mathrm{g} / \mathrm{l}(\mathrm{N}=5)$ in 1995, which again shows no long-term change compared with the present $\mathrm{Fe}=1060 \mu \mathrm{g} / \mathrm{l}$ (Table $2 \mathrm{~b}$ ). On the other hand, it is curious that Sharma (1997) reported no detectable fluvial $\mathrm{Fe}$ at detection limit $100 \mu \mathrm{g} / \mathrm{l}$ anywhere in the Kathmandu valley in 1993. There do not appear to be any studies of fluvial As, Co, Cu, Ni, or Zn in Nepal.

The chief result of this paper is that central Nepal does not contain one geographically-limited source of As in that nearly all rivers showed elevated levels of As. Nearly all rivers also showed elevated levels of $\mathrm{Cu}, \mathrm{Co}, \mathrm{Fe}$, and $\mathrm{Ni}$, while fluvial $\mathrm{Zn}$ was very close to the global background level. Therefore, As mineralisation may be associated with mineralisation of $\mathrm{Cu}, \mathrm{Co}, \mathrm{Fe}$, or $\mathrm{Ni}$, but probably not with $\mathrm{Pb}-\mathrm{Zn}$ mineralisation $(\mathrm{Pb}$ and $\mathrm{Zn}$ are almost always associated). In central Nepal the best predictor of fluvial As appears to be $\mathrm{pH}$. Outside the Kathmandu valley, fluvial As decreased when $\mathrm{pH}$ decreased, due to the increase in the number of positively-charged sorption sites on river bed sediment. Inside the polluted Kathmandu valley, fluvial As increased when $\mathrm{pH}$ decreased, due to the organic complexation of As and the negative correlation between organic matter and $\mathrm{pH}$.

The important question now is how the level of groundwater As in a region is related to the level of fluvial As in the rivers that drain into that region. Neku and Tandukar (2002) have shown that groundwater As is high in the Terai region of central Nepal, but not eastern or western Nepal. The next step will be to study the concentrations of As and other heavy metals in the tributaries of the Karnali River, which drains into the western Terai, and the Sapta Koshi River, which drains into the eastern Terai. 


\section{ACKNOWLEDGEMENTS}

The author is grateful to Professor B. N. Upreti for inviting him to teach and carry out research at Tri-Chandra Campus, Kathmandu, Nepal during 2003. Dr D. P. Adhikari, Dr D. Pathak, Mr. G. Neupane, Mr. S. Shah, and Dr L. Smith assisted with collection of samples. This work was partially funded by a Fulbright Lecturer / Researcher Award through USEF (United States Educational Foundation) Nepal.

\section{REFERENCES}

Acharyya, S. K., Chakraborty, P., Lahiri, S., Raymahashay, B. C., Guha, S., and Bhowmik, A., 1999, Arsenic poisoning in the Ganges delta. Nature, v. 401, 545p.

Acharyya, S. K., Lahiri, S., Raymahashay, B. C., and Bhowmik, A., 2000, Arsenic toxicity of groundwater in parts of the Bengal basin in India and Bangladesh: The role of Quaternary stratigraphy and Holocene sea-level fluctuation. Environ. Geol., v. 39, pp. 1127-1137.

Appelo, M., Van der Weiden, M. J. J., Tournassat, C., and Charlet, L., 2002, Surface complexation of ferrous iron and carbonate on ferrihydrite and the mobilisation of arsenic. Environ. Sci. Technol., v. 36, pp. 3096-3103.

Aswathanarayana, U., 1997, Arsenic in groundwater, West Bengal. J. Geol. Soc. India, v. 49, pp. 341-345.

Badal, K. M., Roy Choudhury, T., Samanta, G., Basu, G. K., Chowdhury, P. P., Chanda, C. R., Lodh, D., Karan, N. K., Dhar, R. K., Tamili, D. K., Das, D., Saha, K. C., and Chakraborti, D., 1996, Arsenic in groundwater in seven districts of West Bengal, India - The biggest As calamity in the world. Current Sci., v. 70, pp. 976-985.

Bhattacharyya, B.P., 1972, Arsenic mineralisation in parts of Hazaribagh District, Bihar. Indian Min., v. 26, pp. 28-34.

Bhattacharaya, P., Chatterjee, D., and Jacks, G., 1997, Occurrence of As-contaminated groundwater in alluvial aquifers from the Delta Plains, Eastern India: Options for safe drinking water supply. Water Resour. Dev., v. 13, pp. 79-92.

Bose, P. and Sharma, A., 2002, Role of iron in controlling speciation and mobilisation of arsenic in subsurface environment. Water Res., v. 36, pp. 4916-4926.

Boyle, R.W. and Jonasson, I. R., 1973, The geochemistry of arsenic and its use as an indicator element in geochemical prospecting. J. Geochem. Explor., v. 2, pp. 251-296.

Das, S., 1977, A note on prospecting of Amjhore pyrite, Rohtas district, Bihar with discussion on the origin of the deposits. Indian Min., v. 31, pp. 8-23.

Datta, D. K. and Subramanian, V., 1997, Texture and mineralogy of sediments from the Ganges-Brahmaputra-Meghna river system in the Bengal basin, Bangladesh, and their environmental implications. Environ. Min., v. 30, pp. 181-188.

Dhar, R. K., Biswas, B. K., Samanta, G., Mandal, B. K., Chakraborti, D., Roy, S., Jafar, A., Islam, A., Ara, G., Kabir, S., Khan, A. W., Ahmed, S. K., and Hadi, S. A., 1997, Groundwater As calamity in Bangladesh. Current Sci., v. 73, pp. 48-59.

Drever, J. I., 1997, Geochemistry of Natural Waters: Surface and Groundwater Environments, $3{ }^{\text {rd }}$ ed. Prentice Hall, Upper Saddle River, New Jersey, 436 p.

DS, 2002a, Nepal, Central Sheet 1:500,000. Topographical Survey Branch, Department of Survey, Ministry of Land Reform, Kathmandu, Nepal.
DS, 2002b, Nepal, Eastern Sheet 1:500,000. Topographical Survey Branch, Department of Survey, Ministry of Land Reform, Kathmandu, Nepal.

Emerman, S. H., 2004, Deforestation, arsenic, and the selforganising jungle in the Terai region of Nepal. J. Nepal Geol. Soc., v. 29, pp. 13-22.

Ghosh, S. and De, S., 1995, Source of the arsenious sediments at Kachua and Itina, Habra Block, North 24 Parganas, West Bengal - A case study. Indian J. Earth Sci., v. 22, pp. 183-189.

Halfpenny, R. and Mazzucchelli, R. H., 1999, Regional multielement drainage geochemistry in the Himalayan Mountains, northern Pakistan. J. Geochem. Explor., v. 67, pp. 223-233.

Harvey, C. F., Swartz, C. H., Badruzzaman, A. B. M., KeonBlute, N., Yu, W., Ali, M. A., Jay, J., Beckie, R., Niedan, V., Brabander, D., Oates, P. M., Ashfaque, K. N., Islam, S., Hemond, H., and Ahmed, M. F., 2002, Arsenic mobility and groundwater extraction in Bangladesh. Science, v. 298, pp. 1602-1606.

Hearn, P., Hare, T., Schruben, P., Sherrill, D., LaMar, C., and Tsushima, P., 2001, Global GIS Database: Digital Atlas of South Asia. U. S. Geological Survey Digital Data Series DDS-62-C.

Lenvik, K., Steinnes, E., and Pappas, A. C., 1978, Contents of some heavy metals in Norwegian rivers. Nord. Hydrol., v. 9, pp. 197-206.

Mallick, S. and Rajgopal, N. R., 1996, Groundwater development in the arsenic-affected alluvial belt of West Bengal - some questions. Current Sci., v. 70, pp. 956-958.

McArthur, J. M., Ravenscroft, P., Safiullah, S., and Thirlwall, M. F., 2001, Arsenic in groundwater: Testing pollution mechanisms for sedimentary aquifers in Bangladesh. Water Resour. Res., v. 37, pp. 109-117.

Neku, A. and Tandukar, N., 2002, A report on arsenic programme (Mitigation measures and a training manual). Department of Water Supply and Sewerage, Ministry of Physical Planning and Works, Kathmandu, Nepal, 53 p.

Nickson, R. T., McArthur, J. M., Burgess, W. G., Ahmed, K. M., Ravenscroft, P., and Rahman, M., 1998, Arsenic poisoning of Bangladesh groundwater. Nature, v. 395, p. 338.

Nickson, R. T., McArthur, J. M., Ravenscroft, P., Burgess, W. G., and Ahmed, K. M., 2000, Mechanism of arsenic release to groundwater, Bangladesh and West Bengal. Appl. Geochem., v. 15 , pp. 403-413.

Pandey, P. K., Yadav, S., Nair, S., and Bhui, A., 2002, Arsenic contamination of the environment: A new perspective from central-east India. Environ. Int., v. 28, pp. 235-245.

Reimann, C. and Filzmoser, P., 2000, Normal and lognormal data distribution in geochemistry: Death of a myth, Consequences for the statistical treatment of geochemical and environmental data. Environ. Geol., v. 39, pp. 1001-1014.

Salbu, B., Pappas, A. C., and Steinnes, A. C., 1979, Elemental composition of Norwegian rivers. Nord. Hydrol., v. 10, pp. 115-140.

Sanders, L. L., 1998. A Manual of Field Hydrogeology. Prentice Hall, Upper Saddle River, New Jersey, 381 p.

Shanker, R., Pal, T., Mukherjee, P. K., Shome, S, and Sengupta, S., 2001, Association of microbes with arsenic-bearing siderite concretions from shallow aquifer sediments of Bengal delta and its implication. J. Geol. Soc. India, v. 58, pp. 269-271.

Sharma, C. K., 1988, Natural Hazards and Man-Made Impacts in the Nepal Himalaya. Mrs. Pushpa Sharma, Kathmandu, Nepal, $142 \mathrm{p}$.

Sharma, C. K., 1995a. Mineral Resources of Nepal. Mrs. Sangeeta Sharma, Kathmandu, Nepal, 142 p. 
Sharma, C. K., 1995b, Some Symptoms of Environmental Degradation in Nepal (1950-1994). Mrs. Sangeeta Sharma, Kathmandu, Nepal, 171 p.

Sharma, C. K., 1997, A Treatise on Water Resources of Nepal. Mrs. Sangeeta Sharma, Kathmandu, Nepal, 493 p.
Smedley, P. L. and Kinniburgh, D. G., 2002, A review of the source, behaviour and distribution of arsenic in natural waters. Appl. Geochem., v. 17, pp. 517-568.

Waslenchuk, D. G., 1979, The geochemical controls on arsenic concentrations in southeastern United States rivers. Chem. Geol., v. 24, pp. 315-325. 